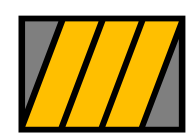

EsCuela de Negocios Universidad Torcuato Di Tella centro de investigación en finanzas

Documento de Trabajo 07/2011

\title{
The Political Economy of Sovereign Defaults
}

\author{
Eugenia Andreasen \\ European University Institute
}

Guido Sandleris

Universidad Torcuato Di Tella

and

Alejandro Van Der Ghote

Princeton University 


\title{
The Political Economy of Sovereign Defaults*
}

\author{
Eugenia Andreasen ${ }^{\dagger}$ \\ European University Institute \\ Guido Sandleris ${ }^{\ddagger}$ \\ Universidad Torcuato Di Tella \\ Alejandro Van der Ghote ${ }^{\S}$
Princeton University
}

September, 12th, 2011

\begin{abstract}
In times of crises, sovereign debt repayment typically depends on the implementation of fiscal programs. In order to implement these programs, governments usually need to garner some political support. The literature on sovereign defaults has not paid attention to the presence of political constraints, assuming, instead, that governments have always unlimited access to the resources of the economy to repay their debts. In this paper, we analyze how the presence of political constraints affects sovereign governments' borrowing and default decisions. We do so in a standard DSGE model with endogenous default risk where we introduce two novel features: heterogeneous agents in the domestic private sector and a requirement that the government obtains some of their support to implement a fiscal program needed to repay the debt. In this framework, we show that there can be different types of sovereign default events. Default can arise because the government is unwilling to repay, in the best tradition of the sovereign debt literature, but also due to insufficient political support even if a benevolent government would prefer to repay. We calibrate the model to the Argentine economy and show that, once political constraints are taken into account, the matching with the data of standard sovereign debt models is weaker than previously understood.
\end{abstract}

*The authors wish to thank seminar participants at Universidad Torcuato Di Tella and the Central Bank of Chile for their useful comments and suggestions. All remaining errors are our own.

†eugenia.andreasen@eui.eu

${ }^{\ddagger}$ Corresponding author: Universidad Torcuato Di Tella, Saenz Valiente 1010, Buenos Aires, Argentina.email: gsandleris@utdt.edu

§anvan@princeton.edu 


\section{Introduction}

In the months prior to the Argentine sovereign default of 2001 and, more recently, during the debt crises in Greece and Portugal, the governments of these countries faced tough political battles when they tried to implement the fiscal adjustments, required to avoid sovereign default. Greece, for example, has implemented several fiscal austerity packages since 2009. Nevertheless, these adjustments have been insufficient to bridge the budget gap and solve the debt crisis. Furthermore, the austerity packages have been met by growing civil unrest and political opposition that might make further adjustments politically unfeasible. ${ }^{1}$ In the case of Portugal, in March 2011, the government proposed a package of austerity measures to restore fiscal balance and debt sustainability. However, opposition parties refused to back the proposal. This led the Portuguese Prime Minister to resign and prompted the need for a European Union - International Monetary Fund rescue package in order to enable Portugal to meet the $€ 4.9$ billion of bond redemptions due in mid-June 2011.

Another example of political battles bringing a country close to default is what happened in the US in mid 2011. At the time, the US government risked defaulting on its debt as a result of disagreements between Democrats and Republicans regarding the characteristics of a fiscal package that aimed to reduce the deficit.

The presence of political constraints that limit the margin of action of governments during the run-ups to sovereign debt crises seems the rule rather than the exception. However, the literature on sovereign default has abstracted from them, assuming that governments have unlimited access to the country's resources. ${ }^{2}$ This implies that the default or repayment decision is essentially determined by the government's will. ${ }^{3}$

The real world sovereign default universe is richer than the traditional theoretical depiction of it. In many circumstances, sovereign defaults are not the result of the governments' unwillingness to repay but of the tough political opposition they face when trying to raise the funds necessary to repay the debt.

This paper analyzes how the presence of political constraints affects sovereign governments' borrowing and default decisions. We do this by introducing

\footnotetext{
${ }^{1}$ In a recent report Roubini Global Economics View, stated that: "...the consensus of the population is an indispensable ingredient when attempting to stick to the plan and seeing the necessary but painful reforms through. Without it, the risk of political collapse, disorderly default (...) increases significantly".(Roubini Global Economics View, 21 June 2011)

${ }^{2}$ These resources are also assumed to be sufficient to repay the debt in the case the government decides to do so.

${ }^{3}$ Papers that analyze the political economy of sovereign defaults can be classified in two main groups. First, there is a set of studies that illustrates the political costs of sovereign defaults related to the fact that a fraction of sovereign debt is usually held by local voters. Among them are Dixit and Londregan (2000), Tabellini (1991) and Guembel and Sussman (2009). The other group of papers analyzes how political turnover affects the government's incentives to borrow from foreign lenders and to repay the debt. Amador (2003), Cuadra and Sapriza (2008), and Hatchondo, Martinez and Sapriza (2009) are the main references of this group. See Hatchondo and Martinez (2010) for a good summary of this literature.
} 
in a standard dynamic stochastic general equilibrium (DSGE) model with endogenous sovereign default risk, as the ones developed in Aguiar and Gopinath (2006) and Arellano (2008), two novel features: heterogeneous households and a requirement that the government garners some of their support to repay its sovereign debt. Heterogeneity across households generates different opinions regarding the convenience of repaying the sovereign debt. The second feature gives households the power to reject a government policy and reflects the fact that the government does not have unlimited access to the country's resources, it can only access these resources if it has enough political support (i.e. enough households that support repayment).

The introduction of these two novel features in a standard sovereign debt model generates a richer typology of sovereign default events. In contrast with the standard sovereign debt literature, in this framework, sovereign defaults are not exclusively determined by the government's unwillingness to repay. Moreover, two new types of default events arise in our model that capture situations in which the government is unable to repay. These events can occur either because the government cannot raise sufficient funds to repay even if it could access all the resources in the economy, or, alternatively, because the fiscal programs that raise sufficient funds are not politically feasible.

This framework also allows us to understand why individuals might disagree on the funding policy the government should implement in order to repay sovereign debt and how these disagreements can affect the government's repayment capacity.

The basic structure of the model is the following. There is a small open economy inhabited by a benevolent government and a continuum of households. Households differ in the share that they receive from the stochastic aggregate income. The government borrows from foreign creditors using non-contingent bonds with the objective of smoothing households' consumption paths. The non-contingent nature of the debt contracts captures the actual terms of international financial markets for sovereign debt.

The political economy restriction becomes relevant when the government needs to repay its debt. If the government wants to repay, it needs to propose a fiscal program to raise the necessary funds. The fiscal program must achieve a minimum level of political support from the households in order to be implemented. As households are heterogeneous in their income levels, the fiscal program may have a different impact on the consumption of each household, leading some of them to reject the program and others to support it. If the minimum level of political support is not reached the government is forced to default. Both if the default is due to the political economy constraint or the government's preferences, it triggers a temporary exclusion from international financial markets and direct output costs. The interest rate specified in the bond contracts reflects the endogenous default probabilities.

We calibrate the model to the Argentine economy. From an ex-post perspective, the presence of the political constraint enlarges the set of sovereign debt levels for which the government defaults. Nevertheless, the quantitative analysis shows that the equilibrium level of sovereign debt is lower, defaults 
are less frequent and interest rates are lower in our model than in standard sovereign debt models. This happens because from an ex-ante perspective the country is better off avoiding default. As a result, the government chooses lower levels of sovereign debt, which eventually trigger fewer defaults reducing the interest rate. All in all, this means that the matching with the data of the standard sovereign debt model, once the political constraint is taken into account, is actually weaker than the one showed by Aguiar and Gopinath (2006) and Arellano (2008). Since the empirical evidence calls for the need to include this constraint, our paper shows that the understanding of the links between sovereign default, sovereign spreads rate and business cycles is less thorough than previously thought and further analysis on the topic is required.

The paper is organized as follows: Section II presents the theoretical model and characterizes the equilibrium, Section III classifies the different types of defaults that arise in our model, Section IV calibrates the model to the Argentine economy and assesses its quantitative implications and Section V concludes.

\section{The model}

\subsection{Environment}

Consider a small open economy inhabited by a continuum of households and a benevolent government. Households are risk averse and have the same preferences. Each household's income is equal to $y_{i}^{r}=\alpha_{i} y$, where $\alpha_{i}$ is the constant share of the aggregate endowment $y$ that household $i$ receives. The aggregate endowment follows a Markov process with transition density $f\left(y^{\prime}, y\right)$ defined on a compact subset $Y \subset \mathbb{R}_{+}$. Households derive utility from consumption:

$$
U\left(c_{i}\right)=E_{0} \sum_{t=0}^{\infty} \beta^{t} u\left(c_{i t}\right)
$$

where the function $u(c)$ denotes the strictly concave and increasing Bernoulli utility function and $\beta$ refers to the subjective discount factor. As it is standard in sovereign default studies, we choose a CRRA functional form for the Bernoulli utility function:

$$
u\left(c_{i t}\right)=\frac{c_{i t}^{1-\sigma}-1}{1-\sigma}
$$

The government is benevolent and thus maximizes aggregate well-being (i.e. social welfare). Social welfare is defined as the sum of utility levels across individual households. Formally:

$$
W=\int_{\Omega} E_{0} \sum_{t=0}^{\infty} \beta^{t} u\left(c_{i t}\right) d i
$$

where $\Omega$ refers to the households' population set, which has unit measure. 
The government has the technology to set uniform lump-sum subsidies or taxes, $\tau$, across individual households. ${ }^{4}$ In addition, the government is the only agent within the small economy who has access to international credit markets. In each period, the government issues one period zero-coupon bonds and sells them to the foreign lenders. We denote by $B^{\prime}$ the amount of debt that the government has issued in the current time period and that promises a payment to bond holders of $B^{\prime}$ units of consumption in the following period. If $B^{\prime}<0$ the government is a debtor, otherwise it holds assets. When the government issues debt, it obtains $B^{\prime} q\left(B^{\prime}, y\right)$ units of current consumption, where $q\left(B^{\prime}, y\right)$ refers to the unitary price of sovereign bonds given current aggregate output endowment, $y$, and the amount of debt to be issued, $B^{\prime}$.

Sovereign bonds are assumed to be non-collateralized and defaultable. To repay its sovereign bonds, the government proposes a fiscal program, i.e. a combination of new bond issuances, $B^{\prime}$, and lump sum taxes $\tau$, that households have to approve or reject. For the government to be able to repay the debt, there must exist a fiscal program that satisfies two conditions. First, the fiscal program must generate enough resources. That is, given outstanding bonds issued in the previous period, $B$, the government must be able to issue new bonds, $B^{\prime}$, and to set taxes, $\tau$, such that:

$$
\tau-B^{\prime} q\left(B^{\prime}, y\right) \geq-B
$$

Second, the fiscal program must garner sufficient support from individual households. Households express their approval or rejection for a given fiscal program through a referendum (i.e. voting for or against the program). Given current aggregate output $y$, the political support function that collects the households' approval over a fiscal program $\left(B^{\prime}, \tau\right)$ proposed by the government is defined as:

$$
p\left(B^{\prime}, \tau ; y\right)=\int_{\Omega} p_{i}\left(B^{\prime}, \tau ; y\right) d i
$$

where $p_{i}=1$ if household $i$ votes in favor of the fiscal program and $p_{i}=0$ otherwise. ${ }^{5}$ The fiscal program is approved only if:

$$
p\left(B^{\prime}, \tau ; y\right) \geq p^{r}
$$

where $p^{r} \in[0,1]$ refers to the minimum level of households' approval required to implement a fiscal program.

\footnotetext{
${ }^{4}$ As households cannot have negative consumption, we restrict the lump sum taxes not to exceed the income of the poorest household, i.e.:$$
\tau \leq \min _{i \in \Omega} y_{i}^{r}=y_{\min }^{r}
$$

With some additional notation, one can think of $y_{\min }^{r}$ as the income of the household with lowest income among those that pay taxes. Note that if the population had a measure $|\Omega|$, larger than one, total tax revenues are bounded from above by $|\Omega| y_{\min }^{r}$

${ }^{5}$ We assume individual households responses to be equally weighted within the political support aggregator mechanism.
} 
The parameter $p^{r}$ captures the political independence that the government has in terms of the set of policies it can implement to raise funds. If $p^{r}=0$, households cannot veto any fiscal program proposed by the government, thus, the government faces no political constraint. In contrast, if $p^{r}>0$, households can affect both the choice of the fiscal program that the government makes and the repayment/default outcome.

Note that if there are fiscal programs that satisfy the resource constraint, (1), and the political constraint, (3), the government is able to repay. However, it might still choose not to do it.

If the government defaults, regardless of the cause, it is temporarily excluded from international credit markets. We take the exclusion period to be exogenous and stochastic. Specifically, the reentry time follows an exogenous Poisson process with flow probability equal to $\theta$. Once the economy randomly regains market access, without loss of generality, we assume that it does so with zero debt. While in autarky, the economy suffers an output loss in its aggregate endowment and households consume their individual financial autarky endowments, $y_{i}^{d}$, defined as:

$$
y_{i}^{d}=\alpha_{i} h(y) \leq y_{i}^{r}
$$

where $h(y)$ stands for the output loss function.

Foreign lenders have risk neutral preferences, behave competitively and can trade both the sovereign bond and a risk-free asset that yields $r>0$. Consequently, they are willing to lend to the government as long as they break even in expected value. Foreign lenders are fully aware of the resource and the political economy constrains the government faces. Besides, they recognize the government's incentives to default on the sovereign bonds. Then, in equilibrium, the sovereign bond price perfectly captures the sovereign default risk prevailing in the economy.

\subsection{Value Functions and Recursive Equilibrium}

The timing of events in the economy is as follows. At the beginning of each period, the government observes the current aggregate endowment, $y$, and, given the amount of sovereign debt, $B$, it proposes a fiscal program, $\left(B^{\prime}, \tau\right)$, or it declares a default. If the government proposes a fiscal program, each household then decides whether to approve or reject the proposal. ${ }^{6}$ Households' individual responses are aggregated by the political support function, $p\left(B^{\prime}, \tau ; y\right)$. If their aggregated political support exceeds the threshold $p^{r}$ and the fiscal program raises at least $B$, the government can implement the proposal and repay the debt. Otherwise, the government is forced to default. Finally, consumption takes place. If the government defaults, household $i$ consumes her financial autarky output endowment, $y_{i}^{d}$, while if the government repays, consumption for household $i$ is $y_{i}^{r}-\tau$.

\footnotetext{
${ }^{6}$ For simplicity, we assume that households cannot enter into cooperative arrangements, and that the government cannot commit to ex-post transfers to compensate households.
} 


\subsubsection{Government's problem}

In every period in which the government is current on its debt, it may be able or unable to repay the debt, depending on the level of outstanding debt and on the aggregate income shock. If there is no fiscal program for which both the resource and political constraints are satisfied, then the government is unable to repay and forced to default. Otherwise, it is able to repay and, therefore, it can choose, with the objective of maximizing households' aggregate welfare, whether to do it or not. Let $v_{g}^{0}(B, y)$ be the value function for the government at the beginning of the period:

$$
v_{g}^{0}(B, y)=\left[\begin{array}{ll}
v_{g}^{d}(y) & \text { if } \nexists\left(B^{\prime}, \tau\right) \text { with } \tau \leq y_{\min }^{r}:(1) \text { and (3) hold } \\
v_{g}^{a}(B, y) & \text { otherwise }
\end{array}\right.
$$

where $v_{g}^{d}(y)$ and $v_{g}^{a}(B, y)$ refer to the value of being unable and able to repay respectively. The value function when the government is able to repay, $v_{g}^{a}(B, y)$, is given by:

$$
v_{g}^{a}(B, y)=\max _{\{r, d\}}\left\{v_{g}^{r}(B, y), v_{g}^{d}(y)\right\}
$$

where $v_{g}^{r}(B, y)$ is the value associated with repayment. Note that the value function of default in this model is the same regardless of the cause of the default. Formally, this value is given by:

$$
v_{g}^{d}(y)=\int_{\Omega} u\left(y_{i}^{d}\right) d i+\beta \int_{Y}\left[\theta v_{g}^{0}\left(0, y^{\prime}\right)+(1-\theta) v_{g}^{d}\left(y^{\prime}\right)\right] f\left(y^{\prime}, y\right) d y^{\prime}
$$

When the government repays, it must be the case that its fiscal program satisfies its budget constraint, raising enough funds to honor current debts, and that it achieves enough political approval across households. Then, the government's value function satisfies:

$$
\begin{aligned}
v_{g}^{r}(B, y)= & \max _{\left(B^{\prime}, \tau\right)} \int_{\Omega} u\left(y_{i}^{r}-\tau\right) d i+\beta \int_{Y} v_{g}^{0}\left(B^{\prime}, y^{\prime}\right) f\left(y^{\prime}, y\right) d y^{\prime}, \\
& \text { subject to (1) and (3) }
\end{aligned}
$$

and the fiscal program it proposes is the solution to this problem.

Since the government anticipates the voting strategy of the households, without loss of generality, we assume that it only proposes fiscal programs that end up being approved. Then, we characterize the default set $D(B)$ and repayment set $R(B)$ as:

$$
D(B)=\left\{y \in Y: \begin{array}{ll}
\text { if } \nexists\left(B^{\prime}, \tau\right) \text { with } \tau \leq y_{\min }^{r}:(1) \text { and (3) hold } \\
\text { or } v_{g}^{r}(B, y)<v_{g}^{d}(y)
\end{array}\right\}
$$

and:

$$
R(B)=\left\{y \in Y: v_{g}^{r}(B, y) \geq v_{g}^{d}(y)\right\},
$$

When repaying, the proposed fiscal program $\left(B^{\prime}(B, y), \tau^{\prime}(B, y)\right)$ is the one that solves problem (6). 


\subsubsection{Households' problem}

Households maximize their utility by choosing whether to approve or reject the government fiscal program. A household that approves the proposal wants the government to repay while a household that rejects it wants the government to default. Let $p_{i}\left(B^{\prime}, \tau ; y\right)$ be the optimal voting decision for household $i$, given current aggregate output $y$ and the government fiscal program $\left(B^{\prime}, \tau\right):^{7}$

$$
p_{i}\left(B^{\prime}, \tau ; y\right)=\left[\begin{array}{l}
1 \text { if } v_{i}^{r}\left(B^{\prime}, \tau ; y\right) \geq v_{i}^{d}(y) \\
0 \text { if } v_{i}^{r}\left(B^{\prime}, \tau ; y\right)<v_{i}^{d}(y)
\end{array}\right.
$$

where 1 stands for voting in favor and 0 for voting against, and $v_{i}^{r}\left(B^{\prime}, \tau ; y\right)$ and $v_{i}^{d}(y)$ are the value functions, from household $i$ perspective, of the government repaying by implementing a fiscal program $\left(B^{\prime}, \tau\right)$ and defaulting, respectively. Formally, these value functions are given by:

$$
\begin{gathered}
v_{i}^{r}\left(B^{\prime}, \tau ; y\right)=u\left(y_{i}^{r}-\tau\right)+\beta \int_{Y} v_{i}^{0}\left(B^{\prime}, y^{\prime}\right) f\left(y^{\prime}, y\right) d y^{\prime} \\
v_{i}^{d}(y)=u\left(y_{i}^{d}\right)+\beta \int_{Y}\left[\theta v_{i}^{0}\left(0, y^{\prime}\right)+(1-\theta) v_{i}^{d}\left(y^{\prime}\right)\right] f\left(y^{\prime}, y\right) d y^{\prime}
\end{gathered}
$$

where $v_{i}^{0}(B, y)$ denotes the value, from household's $i$ point of view, of living in an economy where the government has access to credit markets, given outstanding debts $B$ and aggregate output $y$.

Since households anticipate the government behavior, $v_{i}^{0}(B, y)$ is:

$$
v_{i}^{0}(B, y)=\left[\begin{array}{cc}
v_{i}^{r}\left(B^{\prime}(B, y), \tau^{\prime}(B, y) ; y\right) & \text { if } y \in R(B) \\
v_{i}^{d}(y) & \text { if } y \in D(B)
\end{array}\right.
$$

\subsubsection{Foreign lenders' problem}

Foreign lenders understand that default can happen with a positive probability when they lend to the government. Since foreign lenders behave competitively and have risk-neutral preferences, the expected return of lending to the government should equal the risk free interest rate. This implies that the sovereign bond price satisfies:

$$
q\left(B^{\prime}, y\right)=\frac{1-\operatorname{Pr}\left[D\left(B^{\prime}\right) \mid Y=y\right]}{1+r}
$$

\subsubsection{Recursive Equilibrium}

A Recursive Equilibrium for this economy is: $i$ ) a government policy set, $\left.\left\{\left(B^{\prime}(B, y), \tau^{\prime}(B, y)\right) ; R(B) ; D(B)\right\} ; i i\right)$ a household's $i$ voting strategy, $p_{i}\left(B^{\prime}, \tau ; y\right)$, iii) a sovereign bond price function, $q\left(B^{\prime}, y\right)$ and $\left.i v\right)$ a political support function, $p\left(B^{\prime}, \tau ; y\right)$, such that:

\footnotetext{
${ }^{7}$ We assume that indifferent households approve the government's proposal.
} 
1. Given the sovereign bond price function $q\left(B^{\prime}, y\right)$ and the political support function $p\left(B^{\prime} ; B, y\right)$, the government's policy set $\left\{\left(B^{\prime}(B, y), \tau^{\prime}(B, y)\right) ; R(B) ; D(B)\right\}$ satisfies the government's optimization problem.

2. Given the government's policy set $\left\{\left(B^{\prime}(B, y), \tau^{\prime}(B, y)\right) ; R(B) ; D(B)\right\}$, the household's voting strategy $p_{i}\left(B^{\prime}, \tau ; y\right)$ satisfies the household's optimization problem.

3. The sovereign bond price function $q\left(B^{\prime}, y\right)$ reflects the government's default probability and satisfies the foreign lenders' break-even condition.

4. The political support function $p\left(B^{\prime}, \tau ; y\right)$ is consistent with households voting strategies.

\subsection{Discussion: key ingredients of the model}

Our model departs from standard sovereign debt models in two crucial ways: we assume that households are heterogeneous and that the government needs some amount of households' support (i.e. the political constraint) to implement its desired policy. The first assumption gives rise to potential disagreements among households and between households and the government regarding the optimal policy to be implemented.

The second assumption captures the fact, observed during real sovereign debt crises, that governments need some degree of political approval to implement a fiscal program to repay their debts. The presence of such a political constraint is also key in our model since it gives households a way to veto the government desired policies. ${ }^{8}$

Technically, in our model, differences in opinion across households regarding the optimal policy to be implemented, follows from the combined effect of households' income distribution, the uniform lump-sum taxes assumption and the assumed CRRA Bernoulli utility function. ${ }^{9}$ Since the CRRA utility function implies strict concavity and constant relative risk aversion with respect to income, wealthy households are willing to tolerate higher lump-sum taxes than poorer households in order to repay the debt. In other words, wealthy households would prefer to repay more often than poorer ones.

To better understand the mechanism at play in our model, we can consider alternative scenarios where the aforementioned assumptions do not to hold.

\footnotetext{
${ }^{8}$ More generally, we could say that our model departs from standard sovereign debt models by leaving behind the assumption that governments are autocracies, i.e. the assumption that governments can always implement the policies they desire to without facing any kind of resource or political constraints. For a government not to be an autocracy in an Eaton and Gersovitz (1981) type of model, two key ingredients are needed: first, there must be a source of discrepancy between the government's optimal policy and the households' preferences to justify a potential opposition by households to the government's desired policies and second, they must have a way to do so. Households' heterogeneity and the political threshold generate these two ingredients in our model. Of course, there are alternative ways to generate them.

${ }^{9}$ We choose this functional form in our calibration to be consistent with most studies in sovereign defaults episodes.
} 
For example, if households were all identical receiving the same income endowment, they would all perfectly agree on the optimal policy to implement. On the other hand, if taxes were uniform but ad-valorem, after-tax income endowments would be proportional across individual households, and hence all of them would display the same preference order over fiscal programs and over the repayment/default decision. ${ }^{10}$

More importantly, differences in opinion between households and the government follow from the aforementioned disagreements across individual households and the social welfare function maximized by the government (i.e. the sum of utility levels across individual households). Then, since households sometimes disagree among themselves, the government preferred policy will sometimes be different from some of the households' preferred one.

\section{A classification of sovereign defaults}

Standard sovereign default models have focused on default episodes in which the government is unwilling to repay. In effect, in most of these models, the government has full access to the resources of the economy, which are assumed to be sufficient to repay the debt, and it does not face political restrictions. Then, a sovereign default can only arise if the government prefers to default rather than to repay (i.e. if the government is unwilling to repay its debts).

In the real world, the sovereign default universe is richer than the traditional theoretical depiction of it. In particular, a distinctive feature is that in many circumstances sovereign defaults are not the result of the government being unwilling to repay but of the tough political opposition that governments sometimes face when trying to implement fiscal programs in order to raise funds to repay. The literature so far has been silent about these different types of default. Indeed, by only focusing on "unwillingness to repay" defaults, the literature has been silent about the notion of different types of sovereign defaults altogether.

The political economy model developed above generates different types of sovereign default episodes and allows us to distinguish between them. Three different types of sovereign defaults may arise. First, we have the "pure inability to repay" type of default. In this situation the default occurs because the government cannot generate enough revenues through taxes and new debt issues to repay its debt. We can formalize this situation for a given level of debt $B$ and aggregate output $y$ as follows:

$$
\tau-q\left(B^{\prime}, y\right) B^{\prime}<-B \forall\left(B^{\prime}, \tau\right) \text { with } \tau \leq y_{\min }^{r}
$$

\footnotetext{
${ }^{10}$ Note that if taxes were not uniform, households might still have different opinions on the policies the government should implement. However, in this case, the government would not only have incentives to borrow from abroad to smooth households' consumption paths across states of nature but would also have incentives to implement redistributional policies. Since in this paper we are not interested in dealing with redistributional issues, we restrict the analysis to uniform tax schemes.
} 
Second, we have the "politically constrained inability to repay" type of default. This type of default is intimately related to the presence of a political constraint. In this case, if the government were required to only meet the resource constraint, it would be able to raise enough funds to repay its debts. However, the presence of the political constraint makes the government unable to find a combination of taxes and debt issuance that raises enough funds to repay and, at the same time, garners sufficient political support as to be implementable. As in the previous type of default, in this situation, the government does not face a choice on whether to default or repay, instead, it has no option but to default. Formally, this type of default is one in which:

$$
\exists\left(B^{\prime}, \tau\right) \text { with } \tau \leq y_{\min }^{r}: \tau-q\left(B^{\prime}, y\right) B^{\prime} \geq-B
$$

but, $\forall\left(B^{\prime}, \tau\right)$ for which the previous equations is satisfied, $p\left(B^{\prime}, \tau ; y\right)<p^{r}$.

The third and last type is the "unwillingness to repay" default. In this type of default, repayment is both economically as well as politically feasible, but the government still prefers to default as this decision maximizes aggregate welfare from the government perspective. That is, there are fiscal programs, $\left(B^{\prime}, \tau\right)$, that generate enough revenues to repay the sovereign debt and, at the same time, would garner sufficient political support to satisfy the political constraint; nevertheless, the government would rather default than implement such a fiscal program. In our model, this type of defaults is formally characterized as:

$$
\begin{aligned}
& \exists\left(B^{\prime}, \tau\right) \text { with } \tau \leq y_{\min }^{r}: \tau-q\left(B^{\prime}, y\right) B^{\prime} \geq-B \text { and } p\left(B^{\prime}, \tau ; y\right) \geq p^{r}, \\
& \text { but } v_{g}^{r}(B, y)<v_{g}^{d}(y) .
\end{aligned}
$$

Note that the sovereign debt literature only analyzes a particular case of this latter type of default. One in which the political constraint does not exist (i.e. $p^{r}=0$ ) and the government always has enough resources to make a repayment if it chooses to do so. As a result, in traditional models, sovereign defaults are always due to a government "unconstrained unwillingness to repay".

We can also distinguish our three types of default episodes by partitioning the default set in:

$$
\begin{gathered}
A(B)=\{y \in Y:(1) \text { does not hold }\} \\
A_{c}(B)=\{y \in Y:(1) \text { holds but not }(3)\} \\
W(B)=D(B)-\left\{A(B) \cup A_{c}(B)\right\}
\end{gathered}
$$

where the first set stands for the "pure inability to repay" type of default; the second, for the "politically constrained inability to repay" and the third, for the "unwillingness to repay".

Foreign lenders fully understand how the economy works, so they take into account all possible default events when pricing the sovereign bond. It follows that the sovereign bond price captures the probability of occurrence of the three types of default described above. In this sense, our model shows that foreign lenders consider both the government risks as well as the political economy risks when pricing sovereign debt. 


\section{Calibration and quantitative analysis}

\subsection{Calibration}

We calibrate our theoretical model to the Argentine economy. We focus on the 2001 Argentine debt crisis episode to be able to compare our results with the vast majority of studies in the endogenous default sovereign debt literature.

As it is standard in sovereign default studies, we choose a CRRA functional form for the Bernoulli utility function:

$$
u(c)=\frac{c^{1-\sigma}-1}{1-\sigma}
$$

with a coefficient of relative risk aversion $\sigma$ equal to 2 .

We set the model at the quarterly frequency. We assume the aggregate output to follow an $\operatorname{AR}(1)$ stochastic process:

$$
\ln y_{t}=\rho \ln y_{t-1}+\varepsilon_{t}
$$

with $|\rho|<1$ and $\varepsilon_{t} \sim N\left(0, \sigma_{\varepsilon}^{2}\right)$. To estimate these parameters, we use GDP data taken from the Argentine Ministry of Finance ranging from the first quarter of 1980 to the second quarter of 2001. The GDP time series is in quarterly frequency, in real terms and seasonally adjusted; it is logged and then detrended using a linear filter. Our estimates of $\rho$ and $\sigma_{\varepsilon}$ are 0.945 and 0.025 , respectively.

A relevant feature of our analysis is how we calibrate househoulds' income heterogeneity. We do it using the Argentine income distribution in 1998 as measured by the Center for Distributive, Labor and Social Studies (CEDLAS). ${ }^{11}$ This year is the first one in which they provide information for the whole country. We assume that aggregate output is distributed across three different households' types (poor, middle income and rich) according to:

Table I. Income Distribution for the Argentine economy

\begin{tabular}{ccc}
\hline \hline$\alpha_{1}$ & $\alpha_{2}$ & $\alpha_{3}$ \\
$12 \%$ & $34 \%$ & $54 \%$
\end{tabular}

where $\alpha_{1}$ equals the total share of the income distribution for deciles 1, 2, 3 and $4 ; \alpha_{2}$ for deciles 5, 6, 7 and 8 and $\alpha_{3}$ for the remaining two deciles.

In order to specify the value of the political support threshold $p^{r}$, as a first pass, we assume a simple majority voting process and set $p^{r}=0.5 .{ }^{12}$ We analyze how our results change for a variety of parameter values, including $p^{r}=0$ in which case our results are more similar to those of standard sovereign default models.

\footnotetext{
${ }^{11}$ The CEDLAS is an independent research organization at the Universidad de La Plata, Argentina.

${ }^{12}$ Given that we divide the population in three groups, the first two with $40 \%$ of the population each and the other one with $20 \%$, our results would be the same for any $0.4<p^{r}<0.6$. This changes once we do a finer partition of the population (see section Business Cycle Frequencies).
} 
As in Arellano (2008), we choose an asymmetric output loss function:

$$
h(y)=\min \{y,(1-\lambda) E(Y)\}
$$

where $E(Y)$ stands for the aggregate output unconditional mean and $\lambda$ refers to the percentage aggregate output loss during a sovereign default episode.

The subjective discount factor $\beta$, the re-entry to credit markets probability $\theta$ and the percentage aggregate output loss $\lambda$ are set as in Arellano (2008) for comparability. ${ }^{13}$ Finally, the risk-free interest rate $r$ is set to $1.7 \%$, just to equal the average quarterly interest rate of a 5 year U.S. treasury bond from the first quarter of 1980 to the second quarter of 2001.

Table II summarizes this discussion:

Table II. Parameter Values for Argentina

\begin{tabular}{ccccccc}
\hline \hline$\sigma$ & $\rho$ & $\sigma_{\epsilon}$ & $\beta$ & $\theta$ & $\lambda$ & $r$ \\
2 & 0.945 & 0.025 & 0.953 & 0.282 & 0.96 & $1.7 \%$
\end{tabular}

\subsection{Quantitative analysis}

In this section, we explore the quantitative implications of the theoretical model. First we explain how the presence of the political constraint affects both the government borrowing decision as well as and the repayment/default outcome. Then, we describe some relevant properties of the sovereign bond price function and, finally, we study the simulated business cycle frequencies for the model calibrated to the Argentine economy and compare them to the ones in the data and in standard sovereign default models.

\subsubsection{Effects of the political constraint}

As previously explained, the introduction of a political constraint reduces the feasible set of fiscal programs available to the government. In doing so, it enlarges the default set and reduces the maximum amount of resources the government can borrow from abroad in any given period.

Figure 1 shows the effect on the default set of increasing the political threshold. Higher levels of the political threshold (i.e. higher $p^{r}$ ) imply a reduced set of fiscal programs available to the government and hence more difficulties, and also less incentives, to repay its debt. Thus, the default set grows with $p^{r}$. In particular, the default set is relatively larger for those levels of sovereign debt where repayment is still economically feasible but undesired, or unfeasible due to the political constraint.

\footnotetext{
${ }^{13}$ Arellano (2008) uses a $\theta$ consistent with the empirical findings of Gelos et al (2011) and sets $\lambda$ and $\beta$ to match in her model the standard deviation of the current account and the ratio of debt service to GDP.
} 

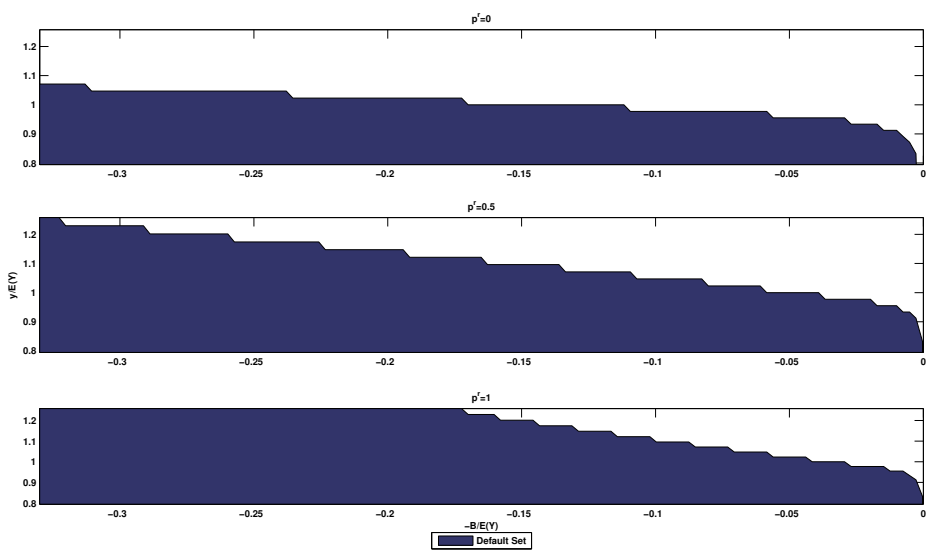

FIGURE 1

Figure 2 shows the effect of $p^{r}$ on the maximum amount of resources that the government can borrow from abroad. Higher $p^{r}$ affects the total resources that the government can borrow as foreign lenders discount the sovereign bond price by its endogenous probabilities of default, and as we explained above, the default set is larger with the constraints.

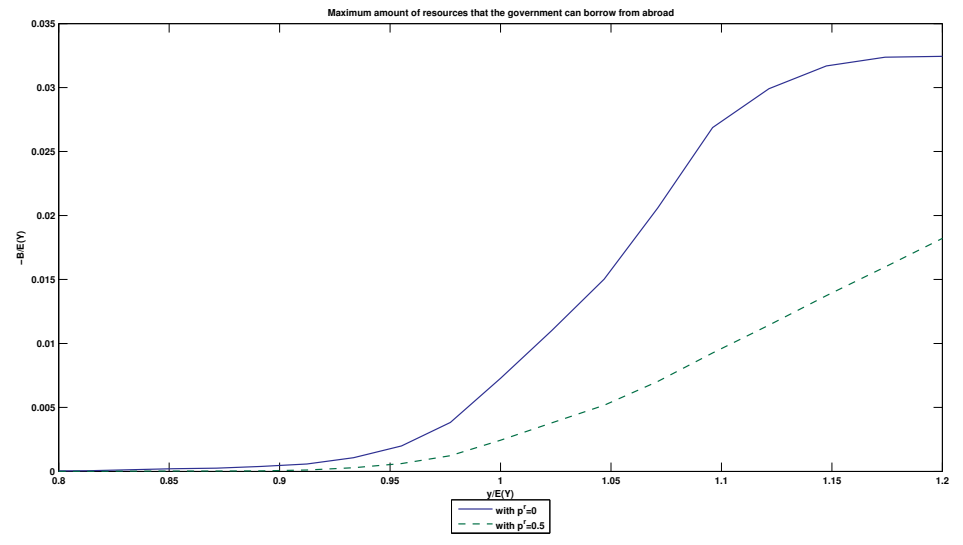

FIGURE 2

We can distinguish two related effects of the political constraint on the government borrowing decision and on the default/repayment outcome: the first 
one, the direct effect, is the result of the government having access to a reduced set of feasible fiscal programs, while the second one, the indirect effect, follows from the lower sovereign bond price function the government faces. Both effects operate in the same direction, namely, both of them make the default set larger and, as a result, reduce the government borrowing capacity. Moreover, both of them reinforce each other: since the government faces a reduced set of feasible fiscal programs, the bond price turns to be lower, and for this reason, the goverment faces an even more reduced set of feasible fiscal programs.

\subsubsection{Relevant properties of the sovereign bond price function}

As it is standard in this literature, the sovereign bond price $q\left(B^{\prime}, y\right)$ decreases as the ratio of debt to GDP goes up. This decline is the result of the increase in the default probability. We can decompose the default probability as a function of the debt to GDP ratio among all the default types that can arise in our model.

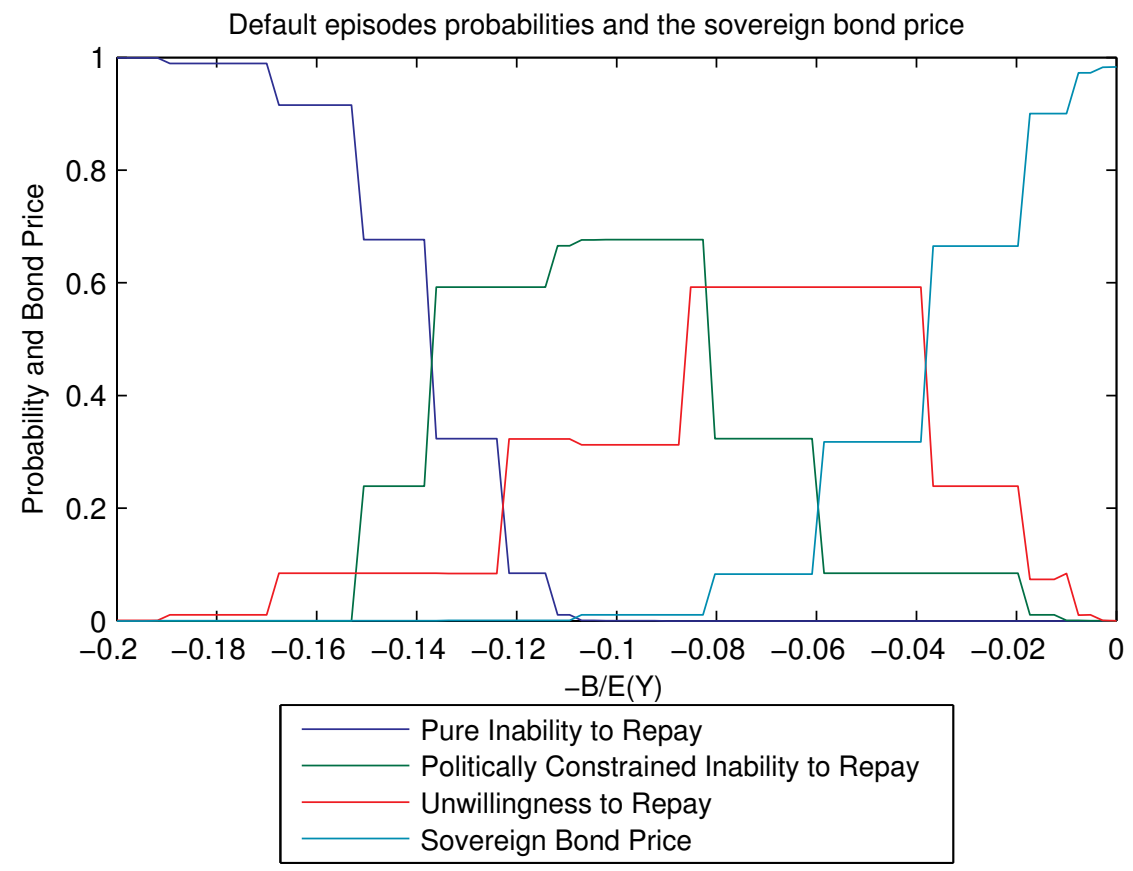

FIGURE 3

In Figure 3 we show the probabilty of each type of default and the sovereign bond price for $p=0.5$. Reasonably, for large debt issuances the likelihood of 
the "pure inability to repay" type of default episodes predominates over the likelihood of the "politically constrained inability to repay" events. However, for ratios of debt to GDP low enough this relationship is reversed. When the government issues lower levels of debt (but not sufficiently low), foreign lenders mostly fear a situation where the government is just unwilling to repay. As the government issues less debt, the overall likelihood of the three types of default episodes decreases. In particular, as the debt to GDP ratio goes to zero, the probability of default goes to zero and the sovereign bond price approaches the price of the risk-free bond.

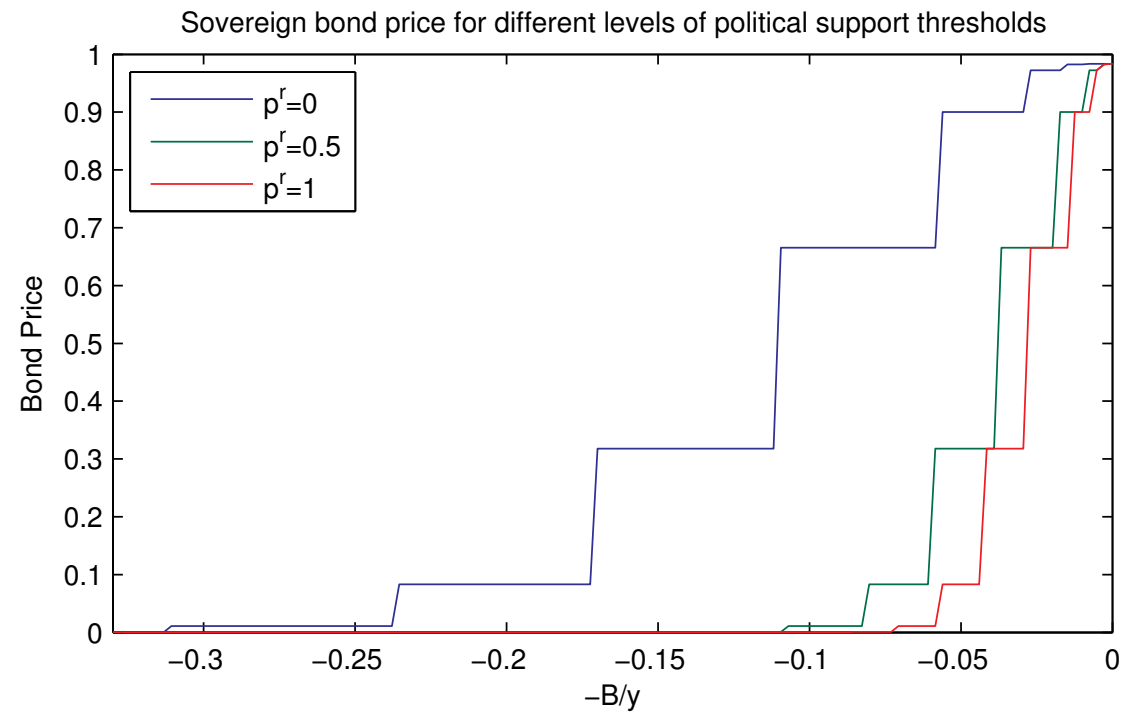

FIGURE 4

Figure 4 shows that range of debt to GDP ratios for which the price is positive is smaller the higher is $p^{r}$. In particular, in the extreme case where $p^{r}=1$, the sovereign bond becomes worthless for output-debt ratios higher than $7 \%$ when the aggregate output is at trend level. In this case, foreign lenders demand very high returns since they know that in future the government will either be unable or have little incentives to repay. When $p^{r}=0.5$, the sovereign bond price is zero debt to GDP ratios higher than $11 \%$, while when $p^{r}=0$ this happens for ratios higher than $31 \%$.

Finally, in line with standard sovereign default models, in our model the sovereign bond price rises with aggregate output (keeping constant the level of sovereign debt). This result follows from both the positive serially autocorrelation of aggregate output as well as the positive correlation between individual and aggregate output: when current aggregate output is high, foreign lenders expect individual outputs to remain high in the next period, and making the government more able and willing to repay its debts. 


\subsubsection{Business cycle frequencies}

In the late December of 2001, the Argentine government defaulted on its debt. Following this default, the Argentine economy suffered a deep recession. In the first quarter of 2002, both output and consumption suffered a massive contraction, falling by $14 \%$ and $16 \%$ below their linear trend, respectively. In addition, in this same quarter, interest rate spreads spiked to almost 30\% per year.

Table IV. Business Cycle Statistics for Argentina

\begin{tabular}{lccc}
\hline \hline & & & \\
Decline from trend during default episode & & \\
\hline & & & \\
Output $(y)$ & -16.01 & & \\
Consumption & -14.21 & & corr with $\mathrm{sr}$ \\
& & & -0.88 \\
Standard deviations and correlations & & -0.89 \\
\hline & 7.81 & 1 & 0.70 \\
Output $(y)$ & 8.60 & 0.98 & 1 \\
Consumption & 1.75 & -0.62 & \\
Trade Balance & 5.58 & -0.88 & \\
Interest Rate Spread $(s r)$ & & & \\
& & & \\
Mean Debt/Output ratio & -43.30 & & \\
Mean Interest Rate Spread & 10.35 & &
\end{tabular}

Table IV presents the main statistics for the business cycle of Argentina. Consumption, output and trade balance data are taken from the Ministry of Finance (MECON). All time series are in quarterly frequency, in real terms and seasonally adjusted. Consumption and output series begin in the first quarter of 1980; they are logged and then detrended using a linear filter. Trade balance series begin in the first quarter of 1993; they are divided by output and are expressed in percentage units. For the interest rates we use the Emerging Markets Bond Index (EMBI), taken from Neumeyer and Perri (2005). ${ }^{14}$ Interest rates spread are computed by subtracting the yield of the 5 year U.S. treasury bond from the EMBI. Debt levels are taken from Global Development Finance database.

During the time interval we focus on, Argentine business cycle frequencies were consistent with the usual business cycle frequencies documented for emerging market economies. As Table IV shows, domestic output, consumption and real interest rates displayed high volatility levels; consumption was more volatile than domestic output; real interest rates anticipated the cycle and moved countercyclically, shrinking when domestic output expanded and spiking when output collapsed; and net exports and the current account also displayed a countercyclical behavior. In the default episode, all variables' deviations notably

\footnotetext{
${ }^{14}$ The EMBI is an interest rate index composed of mostly long term maturity Argentina's dollar bonds that starts in the third quarter of 1983.
} 
exacerbated. In particular, in this single period, both output and consumption dropped by almost two times their standard deviations.

To produce business cycle frequencies comparable to the ones documented for the Argentine economy we selected from our simulations time intervals consisting of 74 quarters and ending up in a default episode. Then, we detrended the time series using a linear filter, and we took the average across selected time intervals for the relevant statistics. ${ }^{15}$

Table $\mathrm{V}$ reports the model business cycle frequencies for different levels of $p^{r}$ both for homogenous and heterogeneous households. In the first case, our model and its business cycle frequencies are equivalent to Arellano (2008). We use the case of homogenous households as the benchmark case with which we compare our results with heterogenous households.

Table V. Model Business Cycle Frequencies for Argentina

\begin{tabular}{lccc} 
& \multicolumn{3}{c}{ Households } \\
& Homogenous & \multicolumn{2}{c}{ Heterogeneous } \\
\cline { 3 - 4 } & & $p^{r}=0.5$ & $p^{r}=1$ \\
& & & \\
Output Decline & -9.59 & -9.02 & -10.32 \\
Consumption Decline & -9.48 & -8.99 & -10.31 \\
& & & \\
Std(Output) & 5.78 & 5.82 & 5.90 \\
Std(Consumption) & 6.29 & 5.95 & 5.93 \\
Std(Trade Balance) & 1.39 & 0.45 & 0.21 \\
Std(Spread) & 6.68 & 7.01 & 1.02 \\
& & & \\
Corr(Output, Cons) & 0.97 & 0.99 & 0.99 \\
Corr(Output, TB) & -0.23 & -0.22 & -0.13 \\
Corr(SR, Output) & -0.29 & -0.23 & -0.10 \\
Corr(SR, Cons) & -0.36 & -0.25 & -0.09 \\
Corr(SR, TB) & 0.39 & 0.40 & 0.34 \\
& & & \\
Mean Debt/Output & -5.54 & -1.7 & -0.38 \\
Mean Spread Rate & 4.17 & 3.68 & 0.45
\end{tabular}

When the political constraint only requires the approval of half of households' for the government to be able to implement fiscal programs, i.e. when $p^{r}=$ 0.5 , our model performs reasonably well at the business cycle frequencies. In particular, aggregate consumption and interest rates volatilities are as much as $75 \%$ and $69 \%$ of actual volatilities, respectively; aggregate consumption is more volatile than aggregate output and strongly procyclical; and both interest rates as well as the trade balance are countercyclical.

\footnotetext{
${ }^{15}$ The almost 3000 time intervals selected in our computational experiment match our sample interval for the Argentine economy.
} 
However, in other dimensions, our model displays some mismatches with data (the average debt to GDP ratio and the average spread rate predicted in our model accounts for only $4 \%$ and $36 \%$ of the ones documented in the data, respectively). Failure to match these dimensions of the data is a feature shared with most sovereign debt models in the literature. The fact that the performance of our model is slightly weaker on this regard than other sovereign debt models is the direct result of the enlarged default set that the presence of the political constraint generates. In effect, from an ex-post perspective, the presence of the political constraint enlarges the set of sovereign debt levels for which the government will default. Nevertheless, the equilibrium level of sovereign debt is lower, defaults are less frequent and interest rates are lower in our model than in standard sovereign debt models. This happens because from an ex-ante perspective the country is better off avoiding sovereign defaults. As a result, the government chooses lower levels of sovereign debt, which eventually trigger fewer defaults reducing the interest rate.

When the political constraint requires the approval of all households for the government to be able to implement fiscal programs (i.e. when $p^{r}=1$ ), our model performance is weaker than in the previous case. As Table V evidences, both consumption and interest rates display lower volatility levels and correlations are even weaker. Moreover, during the default episode, the consumption collapse is less significant and the model does not predict the current account reversal. Finally, under this parametrization our model considerably understimates the average debt to output ratio and the average spread rate (if $p^{r}=1$, the former is only equal to $-0.38 \%$ while the latter is $0.45 \%$ ).

Increasing households heterogeneity does not alter much our quantitative results. Table VII reports the numerical results for the model simulated for the case of $p^{r}=0.5$ and in which aggregate output is distributed among five different households types according to:

\begin{tabular}{ccccc}
\multicolumn{4}{c}{ Table VI. Shares in aggregate output } \\
\hline \hline$\alpha_{1}$ & $\alpha_{2}$ & $\alpha_{3}$ & $\alpha_{4}$ & $\alpha_{5}$ \\
$4 \%$ & $8 \%$ & $13 \%$ & $21 \%$ & $54 \%$
\end{tabular}

where $\alpha_{1}$ equals the total share of the income distribution for deciles 1 and 2; $\alpha_{2}$ for deciles 3 and 4 ; and so on. 
Table VII. Model Business Cycle Frequencies with 5 Households' Types

\begin{tabular}{lc}
\hline \hline & $\begin{array}{c}\text { Heterogeneous Ho } \\
p^{r}=0.5\end{array}$ \\
& -9.61 \\
Output Decline & -9.58 \\
Consumption Decline & \\
& 5.58 \\
Std(Output) & 5.95 \\
Std(Consumption) & 0.29 \\
Std(Trade Balance) & 6.57 \\
Std(Spread Rates) & \\
& 0.99 \\
Corr(Output, Cons) & -0.23 \\
Corr(Output, TB) & -0.24 \\
Corr(SR, Output) & -0.25 \\
Corr(SR, Cons) & 0.38 \\
Corr(SR, TB) & \\
Mean Debt/Output & -0.66 \\
Mean Spread Rate & 3.19
\end{tabular}

As in the case with only three different households types, differences in the business cycle frequencies between our model and that in Arellano (2008) are not substantial.

\section{Conclusion}

This paper focuses on the political constraints that governments face when trying to raise funds to repay their debts. In particular, we focus on the political constraints that may limit a government's ability to access the resources required to avoid a default.

In a standard DSGE model with endogenous sovereign debt and default, we introduced two novel features: heterogeneous households and a requirement that the government garners their support to implement a fiscal program to repay the debt. In this framework, a new classification of default episodes arises. First, as it is traditional in this literature, there are defaults that are chosen by the government (i.e. the government is unwilling to repay). However, as a result of the novel features, two other types of defaults can arise: defaults can be the result of the government being unable to repay either because there are not enough resources in the economy, or because there is not enough political support for any fiscal program that generates enough resources to repay.

When we calibrate the model to the Argentine economy, we find that in many dimensions the model matches the data. However, in others its performance is weak. In particular, as most models in this literature, we have trouble matching the debt to GDP ratio. 
We believe that taking into account the presence of political constraints is crucial to gain a better understanding of sovereign debt crises. Our paper constitutes a first step in this direction but more work needs to be done.

\section{References}

\section{References}

[1] Aguiar, M. \& Gopinath, G., 2006. "Defaultable debt, interest rates and the current account," Journal of International Economics, Elsevier, vol. 69(1), pages $64-83$, June.

[2] Amador, M., 2003. "A Political Economy Model of Sovereign Debt Repayment." Stanford University mimeo.

[3] Arellano, C., 2008. "Default Risk and Income Fluctuations in Emerging Economies." American Economic Review 98 (June): 690-712.

[4] Cuadra, G., and Sapriza. H., 2008. "Sovereign Default, Interest Rates and Political Uncertainty in Emerging Markets." Journal of International Economics 76 (September): 78-88.

[5] Dixit, A., and Londregan, J., 2000. "Political Power and the Credibility of Government Debt." Journal of Economic Theory 94 (September): 80-105.

[6] Eaton, J., and Gersovitz, M., 1981. "Debt with potential repudiation: theoretical and empirical analysis". Review of Economic Studies 48, 289-309.

[7] Gelos, G., Sahay, R. and Sandleris, G., 2011. "Sovereign Borrowing by Developing Countries: What Determines Market Access?" Journal of International Economics, Vol. 83(2), March 2011.

[8] Guembel, A., and Sussman, O., 2009. "Sovereign Debt without Default Penalties." Review of Economic Studies 76 (October): 1,297-320.

[9] Hatchondo, J., Martinez, L. and Sapriza, H., 2009. "Heterogeneous Borrowers in Quantitative Models of Sovereign Default." International Economic Review 50 (October): 1,129-51.

[10] Hatchondo, J., Martinez, L., 2010. "The politics of sovereign defaults," Economic Quarterly, Federal Reserve Bank of Richmond, Issue 3Q, pages 291-317.

[11] Neumeyer, A. and Perri, F. 2005. "Business Cycles in Emerging Economies: The Role of Interest Rates." Journal of Monetary Economics, 52(2): 34580 . 
[12] Tabellini, G., 1991. "The Politics of Intergenerational Redistribution". The Journal of Political Economy Vol. 99, No. 2 (Apr., 1991), pp. 335-357

[13] Tauchen, G. and Hussey, R., 1991. "Quadrature-Based Methods for Obtaining Approximate

Solutions to Nonlinear Asset Pricing Models." Econometrica, 59(2): 371-96.

\section{Appendix}

\subsection{Additional default costs for the government}

As evidenced in many sovereign default episodes, after declaring a default, most government officials faced a large number of additional costs which almost did not affect individual households' well-being. For example, after defaulting, most government officials lost their international prestige, their right to participate in international meetings, their influence over the international community, their close ties with other government officials, and so on. ${ }^{16}$ Due to the presence of these additional default costs, government officials may be less eager to default than individual households. In addition, the government, comprised as a whole entity, may display a higher aversion towards default episodes than that usually considered in standard sovereign default models.

To analyze the situation described above we need to depart from the benevolent government assumption. In this section, we assume that the government not only cares about individual households' well-being but also about the additional default costs it faces after defaulting. In particular, we suppose that after defaulting and while in financial autarky the government flow utility is given by:

$$
w^{d}=\int_{\Omega} u\left(y_{i}^{d}\right) d i-c
$$

where $c>0$ stands for the loss in the government utility due to the additional costs it faces. When having access to international credit markets, we assume the government flow utility remains the same as in the baseline model.

Proposition 1 The Default Set is decreasing in the additional default costs $c$. Moreover, if $c$ exceeds a finite cut off $c^{*}$, the government only defaults when it has no other alternative, that is:

$$
D(B)=\left\{y \in Y:(1) \text { or }(3) \text { do not hold } \forall\left(B^{\prime}, \tau\right) \text { with } \tau \leq y_{\min }^{r}\right\}
$$

(Omitted).

Reasonably, the proposition above states that the government aversion to default outcomes increases when it faces higher additional costs. More importantly, this proposition shows that if $c$ is sufficiently high, the government will

\footnotetext{
${ }^{16}$ For an extensive survey on the cost of defaulting from governments perspective see Hatchondo and Martinez (2010).
} 
do as much as it can to honor its outstanding debts. In particular, the government only defaults when it is unable to rapay. The latter feature may shed light on some extravagant Greek President announcements such that he is even willing to sell his family jewelry to honor current sovereign bonds. 